\title{
KINERJA MESIN PEMISAH POTONGAN TANGKAI DAN DAUN TEH
}

\section{THE PERFORMANCE OF SEPARATION MACHINE OF STALKS AND TEA LEAVES}

\author{
Agus Sutejo ${ }^{1}$, Sutrisno Suro Mardjan², Wawan Hermawan², Desrial ${ }^{2}$ \\ ${ }^{1}$ Ilmu Keteknikan Pertanian, Sekolah Pascasarjana, Institut Pertanian Bogor \\ ${ }^{2}$ Departemen Teknik Mesin dan Biosistem, Fakultas Teknologi Pertanian, Institut Pertanian Bogor \\ 凶komunikasi penulis: kensutrisno@yahoo.com \\ DOI:http://dx.doi.org/10.23960/jtep-lv7i3.160-167
}

Naskah ini diterima pada 29 November 2018; revisi pada 17 Desember 2018; disetujui untuk dipublikasikan pada 27 Desember 2018

\begin{abstract}
The quality of dried tea depends on the condition of raw materials and processing methods. The problem in the tea processing is the mixture of stalks and leaves. This research aims to examine the performance of stalks and leaves machine separator based on the difference of suction velocity and the terminal velocity of the materials. The separator was designed according to the physical and aerodynamic properties of tea leaves. The performance of the separator was done by calculating the separating efficiency of five combined treatments and calculating the separating capacity with three feeding treatments. Physical property observation of the tea leaves obtained an average mass $0.143 \mathrm{~kg} / \mathrm{m}^{2}$ which means the theoretical suction pressure needed is about $1.4 \mathrm{~Pa}$. The actual terminal velocity measured as $7.5 \mathrm{~m} / \mathrm{sec}$ for the stalk pieces and $3.0 \mathrm{~m} / \mathrm{sec}$ for the leaf pieces. The optimum separation efficiency is obtained in a combination of $1250 \mathrm{rpm}$ and the distance between mouthpieces 1 to 6 to tray 6-2.5 cm at $97.6 \%$ with an average air intake speed of $3.15 \mathrm{~m} / \mathrm{sec}$. Optimum separating capacity was obtained about $354.29 \mathrm{~kg} /$ hour.
\end{abstract}

Keywords: Terminal velocity, sortation, tea stalk, tea leaf

\begin{abstract}
ABSTRAK
Mutu akhir teh kering sangat bergantung pada kondisi bahan baku dan metode pengolahannya. Permasalahan pada pengolahan teh saat ini adalah tercampurnya potongan tangkai dan daun sehingga mutu akhir teh kering yang didapatkan rendah. Penelitian ini bertujuan menguji kinerja mesin pemisah potongan tangkai dan daun secara pneumatis berbasis perbedaan kecepatan hisap terhadap kecepatan terminal bahan setelah pencacahan pucuk daun teh layu. Mesin pemisah dirancang sesuai dengan sifat fisik dan sifat aerodinamis potongan daun teh. Uji kinerja mesin dilakukan dengan menghitung efisiensi pemisahan pada lima kombinasi perlakuan jarak mulut corong serta menghitung kapasitas kerja mesin pemisah dengan tiga perlakuan pengumpanan bahan. Pengamatan terhadap sifat fisik potongan daun teh menghasilkan rata-rata massa daun teh adalah $0.143 \mathrm{~kg} / \mathrm{m}^{2}$. Dari data tersebut diperoleh kebutuhan tekanan hisap teoritis sebesar 1.4 Pa. Hasil perhitungan kecepatan terminal potongan tangkai dan daun teh masing-masing sebesar $3.8 \mathrm{~m} /$ detik dan $2.45 \mathrm{~m} /$ detik. Efisiensi pemisahan optimum diperoleh pada kombinasi $1250 \mathrm{rpm}$ dan jarak antara mulut corong 1 sampai dengan 6 terhadap tray 6$2.5 \mathrm{~cm}$ sebesar $97.6 \%$ dengan rata-rata kecepatan udara penghisap $3.15 \mathrm{~m} /$ detik. Kapasitas mesin optimum diperoleh sebesar $354.29 \mathrm{~kg} / \mathrm{jam}$.
\end{abstract}

Kata Kunci: Daun teh, kecepatan terminal, sortasi, tangkai daun teh

\section{PENDAHULUAN}

Teh (Camellia sinensis) merupakan salah satu komoditas utama perkebunan Indonesia. Indonesia merupakan salah satu negara produsen teh di dunia, dengan nilai eksport 51.32 ribu ton (US\$ 113.11) ( BPS 2016). Indonesia juga merupakan pengekspor teh terbesar kesembilan di dunia dengan pangsa pasar $2.40 \%$ (FAO 2014). Produksi teh tahun 2016 mencapai 124.16 ribu ton namun selama sepuluh tahun terakhir kinerja agribisnis teh Indonesia menurun. Penurunan kinerja ditunjukkan oleh penurunan luas perkebunan teh sebesar $10.77 \%$ pada 
Perkebunan Besar Negara (PBN) dan 34.01\% pada Perkebunan Besar Swasta (PBS), dan diikuti oleh penurunan produksi sebesar $10.04 \%$ pada kedua perusahaan besar tersebut pada tahun 2016 (BPS 2016).

Kelemahan dalam pengolahan teh adalah tercampurnya batang dan daun teh serta terkoyaknya kulit tangkai yang menurunkan mutu teh. Pencampuran batang dan daun teh dapat menurunkan kualitas produk akhir teh kering. Hal ini karena produk utama teh olahan berkualitas tinggi berasal dari daun teh, sedangkan batang lebih berfungsi sebagai pengotor ketika kulit batang dilepas. Keuntungan memisahkan batang dan daun teh adalah peningkatan kualitas produk teh akhir. Kualitas teh yang berasal dari daun akan meningkatkan nilai jual produk. Hasil pemisahan ini akan menghasilkan daun teh mutu I dan tangkai teh mutu I, etapi jika batang daun teh tidak terlepas dari kulit maka akan diproses menjadi teh kualitas tinggi yang istimewa. Peningkatan mutu teh yang dihasilkan dari proses pemisahan dapat meningkatkan harga daun teh.

Pemisahan tangkai dan daun teh pertama kali dilakukan oleh Edwards (1967). Pemisahan dilakukan dengan merendam campuran tangkai dan daun teh ke dalam media cair organik yang mudah menguap. Tangkai akan mengapung dan daun akan tenggelam ke dasar media tersebut. Kelemahan metode ini adalah media cair yang digunakan cukup mahal, bahan tersebut juga meninggalkan residu yang tercampur dalam kandungan produk teh. Pemisahan serupa dilakukan oleh Gan-Mor (1986) terhadap daun parsley kertiting dari batangnya. Pemisahan ini menggunakan silinder berputar berlapis dan dilengkapi dengan pemisah aliran udara vertikal dan saringan berisolasi. Silinder bagian luar berdiameter $0.25 \mathrm{~m}$ dan panjang $1.0 \mathrm{~m}$, silinder bagian dalam berdiameter $0.8 \mathrm{~m}$ dan panjang 2.0 $\mathrm{m}$, dan pemisah lain sesuai standar komersial.

Kelemahan dari sistem pemisah ini adalah sangat peka terhadap kenaikan laju pengumpanan, tidak dapat beroperasi dengan baik (meluap) pada laju pengumpanan yang tinggi ( $>400 \mathrm{~g} /$ detik).

Pemisahan lain yang berkembang adalah pemisahan berdasarkan kecepatan terminal (terminal velocity). Cara pemisahan ini biasanya diterapkan pada biji-bijian untuk memisahkan biji dengan pengotor yang massa jenisnya berbeda. Ariana (1995) menerapkan prinsip kecepatan terminal ini pada ampas pres buah sawit. Penelitian Ariana (1995) ini menganalisis fungsi kepekatan kecepatan terminal masingmasing fraksi ampas pres buah sawit (serat, biji utuh, biji pecah, inti utuh, inti pecah, cangkang besar, dan cangkang kecil) serta menentukan kecepatan aliran udara pemisahan yang memberikan derajat pemisahan yang terbaik. Sementara Rais (2005) menggunakan prinsip serupa untuk menganalisis proses pemisahan bahan curah secara pneumatik. Hasil penelitiannya menunjukkan jarak lemparan dengan hembusan udara dari blower dipengaruhi oleh kemiringan sudut blower. Kemiringan sudut blower $5^{\circ}$ hasilnya lebih kecil dibandingkan dengan hembusan udara dari blower yang dipasang dengan kemiringan $15^{\circ}$. Panjang jarak lemparan maksimum dengan kecepatan udara $20.882 \mathrm{~cm} /$ detik, sudut blower $15^{\circ}$ dan luas hopper $150 \mathrm{~cm}^{2}$ pada bahan berdiameter $0.4 \mathrm{~cm}$ adalah $2.25 \mathrm{~m}$.

Margana (2008) juga menggunakan prinsip kecepatan terminal untuk menganalisis karakterisasi pemisahan beras, bekatul, dan sekam pada sistem siklon. Lebih lanjut Gürsoy (2010) menganalisis sifat fisik dan aerodinamis beberapa produk pertanian, seperti: gandum, serelia untuk pakan ternak, kacang polong, dan buncis berdasarkan prinsip kecepatan terminal untuk mengembangkan teknologi yang tepat dalam desain mesin pascapanen. Hasil penelitian menunjukkan terminal velocity sebesar 7.52 $8.14 \mathrm{~m} /$ detik untuk varietas gandum, 7.04 - 7.07 $\mathrm{m} /$ detik untuk varietas serelia, $7.72-7.78 \mathrm{~m} /$ detik untuk varietas kacang polong, dan 11.15 $12.01 \mathrm{~m} /$ detik untuk varietas buncis. Berdasarkan penelitian-penelitian terdahulu, pemisahan tangkai dan daun teh hasil cacahan mesin pencacah pucuk daun teh (Sutejo, 2018) dapat dilakukan berdasarkan kecepatan terminal Mesin pemisah daun teh berdasarkan kecepatan terminal telah didesain dan telah dibuat prototipenya, namun belum dilakukan uji kinerjanya. Tujuan penelitian ini adalah menguji kinerja mesin pemisah potongan tangkai dan daun teh layu yang sudah dicacah, dengan mengacu pada karakteristik fisik dan sifat aerodinamis dari daun teh. 


\section{BAHAN DAN METODE}

Bahan yang digunakan dalam uji kinerja ini adalah pucuk teh layu Camellia sinensis varietas Asammica dengan kadar air sekitar 68\% yang diperoleh dari perkebunan PTP Nusantara VIII, Cianten, Bogor, Jawa Barat dan telah dicacah dengan menggunakan mesin pencacah pucuk daun teh. Peralatan yang digunakan untuk pengukuran karakteristik pucuk teh antara lain: gunting, penggaris, timbangan digital, jangka sorong, meteran, blower, anemometer, dan monitor anemometer. Peralatan pengukuran kinerja mesin, antara lain: timbangan, tachometer, anemometer, dan monitor anemometer.

Prototipe mesin pemisah potongan tangkai dan daun teh (Gambar 1) yang telah dibuat terdiri dari mekanisme penggetar yang terdiri dari: tray pemapar potongan pucuk teh dan mekanisme crank and rocker yang digerakkan oleh sebuah motor listrik serta mekanisme penghisapan yang terdiri dari blower yang digerakkan oleh motor listrik bertenaga $3 \mathrm{HP}$ dan kecepatan putar (n) 975, 1250, dan $1425 \mathrm{rpm}$. Mesin pemisah ini dipasangkan dengan mesin pencacah pucuk teh.

Mekanisme kerja mesin ini adalah pucuk teh diumpankan ke mesin pencacah sehingga pucuk teh terpotong-potong dan kemudian jatuh ke tray getar. Tray getar berfungsi untuk meratakan tumpukan potongan pucuk teh dan melontarkan agar bahan turun secara perlahan ke bawah. Di atas tray getar, potongan puck teh yang terdiri dari daun dan tangkai teh bergerak perlahan menuju corong hisap. Pada prinsipnya, tangkai teh yang memiliki massa yang lebih besar dan bentuk seperti silinder akan terlontar lebih jauh dan menggelinding lebih cepat dari pada daun teh, sehingga membuat potongan-potongan yang sebelumnya menumpuk menjadi terurai dan merata pada permukaan tray. Ketika melewati corong hisap daun teh terhisap, sedangkan tangkai teh tidak terhisap dan jatuh ke bawah tray. Hal ini desebabkan karena udara hisap memiliki kecepatan lebih besar dari kecepatan terminal yang dimilik daun teh, tetapi lebih kecil dari kecepatan terminal tangkai teh.

\subsection{Identifikasi sifat fisik dan aerodinamis pucuk daun teh}

Identifikasi sifat fisik dan aerodinamis pucuk daun teh sangat penting dilakukan dalam merancang mesin pemisah berbasis pneumatik. Sifat fisik daun teh yang diidentifikasi terutama adalah dimensi dan massa per satuan luas. Sedangkan sifat aerodinamisnya adalah kecepatan terminal. Kecepatan terminal diukur secara teoritis menggunakan Persamaan 1 dan 2 mengacu Mohsenin (1986). Tangkai diasumsikan berbentuk silinder dengan pajang $L$ dan diameter $d_{s}$ yang merupakan rata-rata aritmetik dari pengukuran diameter di kedua ujungnya dan bagian tengah tangkai. Daun diasumsikan berbentuk piringan dengan diameter $d_{p}$ yang merupakan rata-rata geometrik dari pengukuran dua sumbu terbesar yang saling tegak lurus.

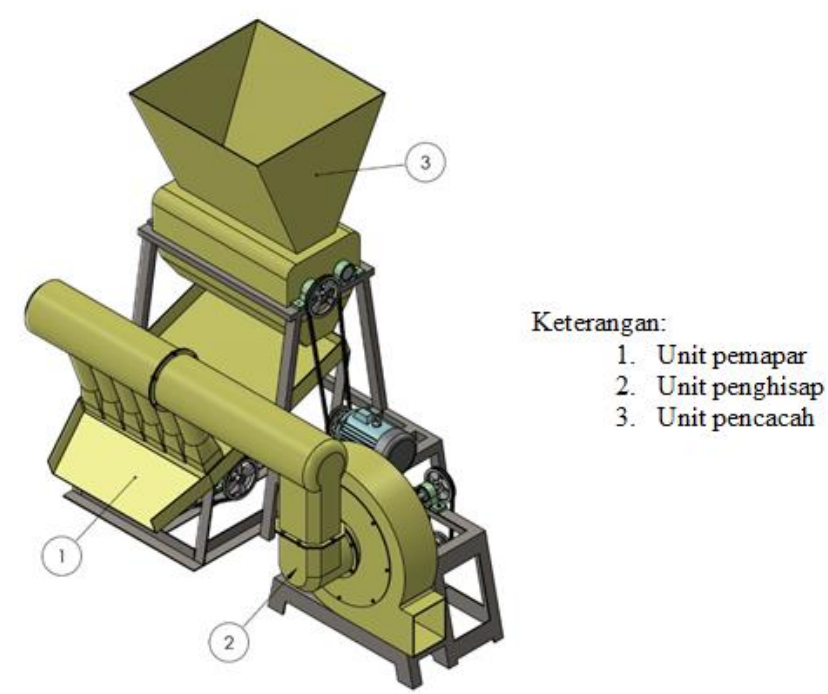

Gambar 1. Mesin pemisah potongan tangkai dan daun teh 
Kecepatan terminal bahan berbentuk silinder adalah sebagai berikut:

$$
v_{t}=\sqrt{\frac{\left(\rho_{p}-\rho_{f}\right) g d_{p}}{2 \rho_{f} C}}
$$

sementara kecepatan terminal bahan berbentuk lembaran adalah sebagai berikut:

$$
v_{t}=\sqrt{\frac{2 g L\left(\rho_{p}-\rho_{f}\right)}{\rho_{f} C}}
$$

Dimana $v_{t}$ : kecepatan terminal $(\mathrm{m} / \mathrm{s}) ; C$ : koefisien geser (1.12 untuk lembaran dan 1.2 untuk silinder); $g$ : percepatan gravitasi $(9.81 \mathrm{~m} /$ $\left.\mathrm{s}^{2}\right)$; $d p$ : diameter (m); $L$ : tebal produk $(\mathrm{m}) ; \rho_{p}$ : densitas produk $\left(\mathrm{kg} / \mathrm{m}^{3}\right) ; \rho_{g}$ : densitas udara $(1.2$ $\mathrm{kg} / \mathrm{m}^{3}$ pada $25^{\circ} \mathrm{C}$ ).

Beberapa contoh potongan daun teh diambil dari hasil pencacahan menggunakan mesin pencacah. Hasil pengukuran luas permukaan terhadap 10 contoh potongan daun teh menunjukkan rata-rata massa daun teh per satuan luas adalah $0.143 \mathrm{~kg} / \mathrm{m}^{2}$. Jika dijumlahkan hingga luas permukaan daun teh seluas permukaan corong hisap $\left(0.01 \mathrm{~m}^{2}\right)$, maka massanya adalah $0.00143 \mathrm{~kg}$ setara dengan berat (W) sebesar $0.014 \mathrm{~N}$. Berdasarkan data tersebut diperoleh kebutuhan tekanan hisap dengan persamaan $\mathrm{P}=\mathrm{F} / \mathrm{A}$ sebesar $1.4 \mathrm{~Pa}$. Tekanan hisap ini dibutuhkan untuk mengetahui total pressure drop dalam analisis kebutuhan daya blower hisap.

\subsection{Pengujian kinerja prototipe mesin}

\subsubsection{Pengukuran kecepatan udara hisap}

Pengukuran kecepatan udara hisap dilakukan untuk mengetahui hubungan perubahan kecepatan putaran blower terhadap kecepatan udara hisap, baik di mulut corong hisap, maupun di permukaan tray di bawah mulut corong. Pengujian ini dilakukan dengan mengukur kecepatan udara hisap menggunakan alat ukur
Hot Wire Anemometer. Pengukuran ini menghasilkan kombinasi perlakuan yang dijadikan acuan dalam pengujian efisiensi pemisahan oleh mesin (Tabel 1).

Unit ini terdiri dari blower hisap, motor listrik, pipa inlet, dan corong hisap. Impeller yang digunakan adalah backward curved impeller dengan jumlah blade sebanyak delapan buah. Tipe impeller ini memiliki bentuk melengkung seperti kurva, sehingga meminimumkan potonganpotongan daun teh tersangkut pada blade ketika berputar. Selain itu, hasil penelitian Oyelami (2008) menyatakan bahwa impeller dengan tipe backward curved menghasilkan aliran udara paling besar dibandingkan tipe forward dan radial. Berdasarkan kondisi kebutuhn kapasitas hisap blower, diperoleh desain impeller dengan inlet radius sebesar $12 \mathrm{~cm}$, outlet radius sebesar $30 \mathrm{~cm}$, dan lebar blade $7.5 \mathrm{~cm}$.

Pengukuran tekanan hisap aktual pada keenam mulut corong penghisap menghasilkan nilai tekanan hisap masing-masing sebesar 206.01 $\mathrm{Pa}, 130.80 \mathrm{~Pa}, 68.67 \mathrm{~Pa}, 55.59 \mathrm{~Pa}$, 49.05 Pa, dan 39.24 Pa. Perbedaan tekanan yang dihasilkan disebabkan oleh perbedaan posisi corong terhadap blower. Nilai aktual tekanan hisap tersebut sudah melebihi tekanan hisap yang diharapkan sehingga mampu mengangkat potongan daun teh yang terpapar pada tray getar. Perhitungan kecepatan terminal potongan tangkai dan daun teh secara teoritis adalah sebesar $3.8 \mathrm{~m} /$ detik dan $2.45 \mathrm{~m} /$ detik. Data kecepatan terminal potongan daun teh ini sangat dibutuhkan untuk menentukan kecepatan udara hisap optimum pada mesin pemisah sehingga pemisahan potongan daun teh dapat berjalan dengan baik.

Kecepatan udara hisap pada masing-masing mulut corong tentu berbeda, hal ini terkait

Tabel 1 Kombinasi perlakuan pengujian efisiensi pemisahan potongan daun teh

\begin{tabular}{cccc}
\hline \multirow{2}{*}{$\begin{array}{c}\text { Putan blower } \\
\text { (rpm) }\end{array}$} & \multicolumn{3}{c}{ Kombinasi jarak mulut corong 1 sampai dengan $\mathbf{6}$ terhadap tray $(\mathbf{c m})$} \\
\cline { 2 - 4 } & $\mathbf{6 . 0 ; 5 . 0 ; 4 . 0 ; 3 . 5 ; 3 . 0 ; 2 . 5}$ & $\mathbf{7 . 0 ; 6 . 0 ; 5 . 0 ; 4 . 5 ; 4 . 0 ; 3 . 5}$ & $\mathbf{5 . 5 ; 4 . 5 ; 3 . 5 ; 3 . 0 ; 2 . 5 ; 2 . 0}$ \\
\hline 1250 & $P$ & - & - \\
1425 & $P 1 a$ & $P 1 b$ & - \\
975 & $P O a$ & - & $P 0 b$ \\
\hline
\end{tabular}




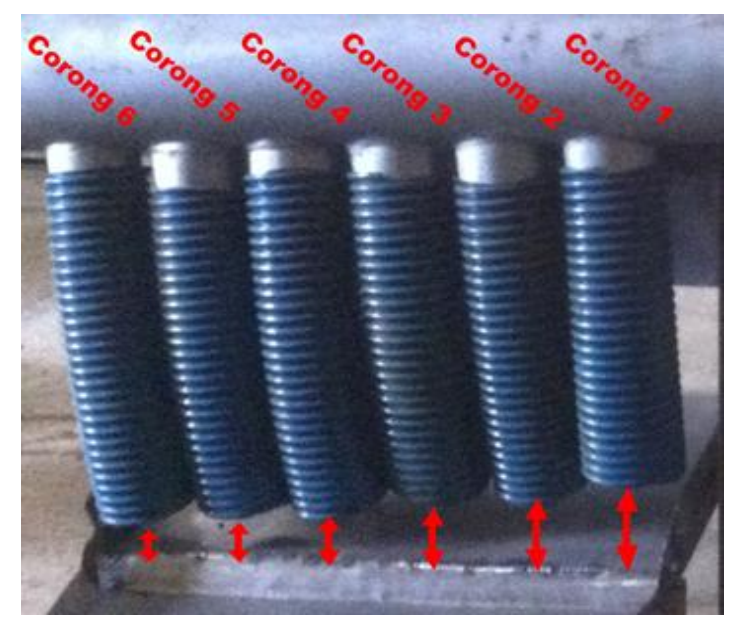

Gambar 2. Posisi corong hisap mesin pemisah potongan tangkai dan daun teh

dengan jarak masing-masing mulut corong terhadap sumber putaran blower. Susunan corong penghisap dapat dilihat pada Gambar 2. Semakin jauh dari sumber putaran blower maka jarak mulut corong ke permukaan tray disusun semakin dekat. Karena jaraknya semakin jauh dengan blower, maka kecepatan udara hisapnya juga semakin kecil.

\subsubsection{Pengukuran efisiensi pemisahan}

Bahan yang keluar dari penghisap ditimbang untuk mengetahui bobot total. Setelah itu, diamati lebih lanjut untuk mengetahui banyaknya tangkai teh yang ikut terhisap bersama daun. Masing-masing daun dan tangkai ditimbang untuk memperoleh bobot keduanya. Mutu penghisapan dihitung menggunakan persamaan 3 yang telah dikembangkan oleh Panasiewich (1998).

$$
\eta=\frac{b}{b_{0}} \times 100
$$

Dimana $\eta$ adalah persentase daun terhisap (\%); $b$ adalah bobot sample terhisap (kg); $b_{o}$ adalah bobot sample input $(\mathrm{kg})$. Hal yang sama dilakukan pada keluaran dari penggetar untuk mengetahui persentase tangkai teh yang tidak terhisap oleh blower.

\subsection{Pengukuran kapasitas kerja mesin pemisah}

Pengukuran kapasitas kerja mesin pemisah yang optimal dilakukan dengan tiga tingkat laju pengumpanan, yaitu: $0.4 \mathrm{~kg} /$ detik, $0.5 \mathrm{~kg} /$ detik, dan $0.6 \mathrm{~kg} /$ detik. Setiap pengujian dilakukan penimbangan bobot bahan pada keluaran unit penggetar dan keluaran unit penghisap, namun yang menjadi parameter kapasitas kerja mesin pemisah adalah bahan yang keluar dari unit penghisap, yaitu potongan daun teh. Pengujian dilakukan pada kecepatan putar blower optimum. Kapasitas kerja mesin pemisah dihitung dengan persamaan 4 .

$$
C=\frac{W_{d}}{t}
$$

Dalam hal ini $C$ adalah kapasitas $(\mathrm{kg} / \mathrm{jam}), W_{d}$ adalah bobot pucuk teh yang terhisap (kg), dan $t$ adalah waktu pemrosesan (jam).

\subsection{Kombinasi perlakuan pengujian efisiensi pemisahan potongan daun teh}

Perlakuan pertama pada uji ini dilakukan dengan kecepatan putaran blower sesuai hasil analisis rancangan, yaitu $1250 \mathrm{rpm}$. Hasil pengukuran diperoleh rata-rata kecepatan udara hisap pada permukaan tray sebesar $3.15 \mathrm{~m} /$ detik. Agar kecepatan udara hisap seragam di sepanjang permukaan tray maka jarak dari mulut corong ke permukaan tray diatur sedemikian rupa sehingga diperoleh ketinggian corong terhadap tray dari corong 1 sampai dengan corong 6 secara berurutan sebesar 6, 5, 4, 3.5, 3, dan 2.5 $\mathrm{cm}$. Pengaturan ketinggian corong pada perlakuan pertama dijadikan sebagai setting acuan untuk perlakuan berikutnya.

Perlakuan kedua menggunakan kecepatan putaran blower 1425 rpm dengan jarak mulut corong hisap ke permukaan tray sama dengan setting acuan. Perlakuan ini dilakukan untuk melihat perubahan kecepatan udara hisap pada permukaan tray jika kecepatan putaran blower ditingkatkan, sedangkan ketinggian corong hisapnya tetap. Hasil pengukuran diperoleh 
kecepatan udara hisap rata-rata permukaan tray sebesar $3.51 \mathrm{~m} /$ detik. Perlakuan ketiga juga dilakuakan menggunakan kecepatan putaran blower $1425 \mathrm{rpm}$, namun dilakukan perubahan kombinasi ketinggian mulut corong penghisap untuk mendapatkan kecepatan hisap sesuai dengan setting acuan. Pada perlakuan ketiga ini diperoleh jarak mulut corong hisap ke permukaan tray dari corong 1 sampai dengan corong 6 berturut-turut sebesar 7, 6, 5, 4.5, 4, dan $3.5 \mathrm{~cm}$ dengan kecepatan udara hisap terukur pada permukaan tray sebesar $3.17 \mathrm{~m} /$ detik.

Perlakuan keempat dan kelima dilakukan pada kecepatan putar blower 975 rpm. Percobaan keempat dengan kombinasi ketinggian corong yang sama dengan setting acuan diperoleh ratarata kecepatan udara hisap di permukaan tray sebesar 2.55 m/detik. Kecepatan hisap tersebut lebih kecil dibandingkan dengan kecepatan terminal potongan daun teh sehingga perlu dilakukan pengaturan ulang terhadap ketinggian corong hisap. Hasil pengaturan ulang diperoleh kombinasi ketinggian corong 1 sampai dengan corong 6 berturut-turut sebesar 5.5, 4.5, 3.5, 3, 2.5, dan $2 \mathrm{~cm}$. Kombinasi ketinggian corong tersebut memiliki rata-rata kecepatan udara hisap terukur pada permukaan tray adalah 3.16 $\mathrm{m} /$ detik. Lima kombinasi perlakuan uji efisiensi pemisahan disajikan pada Tabel 1.

\section{HASIL DAN PEMBAHASAN}

Daun teh hasil pemisahan ditunjukkan pada Gambar 3. Hasil cacahan pucuk daun teh menggunakan mesin pencacah pucuk daun teh berupa daun dan tangkai teh yang tercampur. Campuran daun dan tangkai daun teh ini dapat terpisahkan dengan menggunakan mesin pemisah daun dan tangkai daun teh. Daun teh akan tersedot blower mesin pemisah, sedangakan batang tidak ikut tersedot blower karena berat per satuan luas proyeksi lebih besar dibandingkan dengan daun. Gambar 3(a) menunjukkan daun teh yang terpisahkan dari tangkainya (terhisap blower mesin pemisah) dan 3(b) tangkai daun teh yang terpisahkan dengan daun teh (tidak terhisap). Namun pada mesin pemisah daun tangkai daun teh ini ada daun dan batang yang tidak terpisahkan, 3(c) daun tidak terpisahkan (tidak terhisap), dan 3(d) tangkai tidak terpisahkan (ikut terhisap blower mesin pemisah).

\subsection{Efisiensi pemisahan}

Efisiensi pemisahan ditunjukkan oleh besarnya persentase potongan daun teh yang terhisap oleh blower dan tertampung dalam wadah penampung potongan daun teh. Semakin banyak potongan daun teh yang dapat dipisahkan dari tangkainya, maka efisiensi pemisahan semakin tinggi. Pemisahan terhadap keluaran cacahan daun teh pada lima kombinasi perlakuan ditunjukkan pada Gambar 4. Persentase daun terhisap yang paling tinggi adalah pada perlakuan putaran blower 1425 rpm dengan ketinggian corong hisap sama dengan setting acuan $(P 1 a)$, yaitu sebesar $81.32 \%$, kemudian diikuti oleh kombinasi perlakuan $P$ sebesar $79.82 \%$. Sedangkan persentase daun terhisap terendah adalah pada perlakuan $P 0 a$, yaitu $66.54 \%$. Hal tersebut tidak menunjukkan $P 1 a$ sebagai kombinasi perlakuan terbaik.

Efisiensi mesin pemisah potongan tangkai dan daun teh dikategorikan baik jika persentase daun terhisap tinggi dan persentase tangkai terhisap rendah, karena banyaknya tangkai yang terhisap

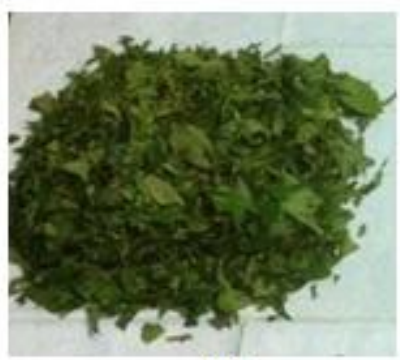

(a)

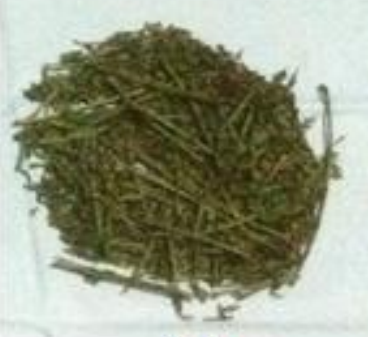

(b)

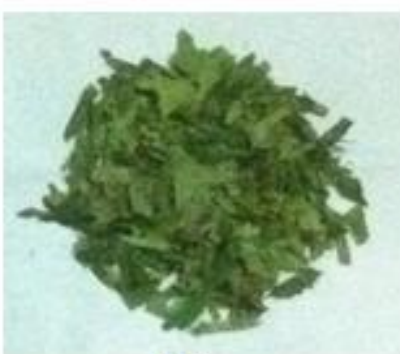

(c)

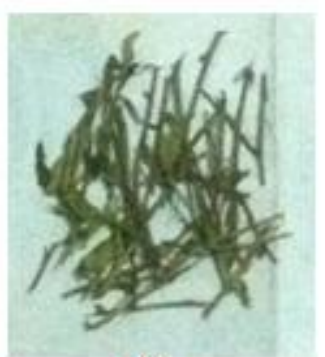

(d)

Gambar 3. Hasil pemisahan: (a) daun terhisap, (b) tangkai tidak terhisap, (c) daun tak terhisap, (d) tangkai terhisap 


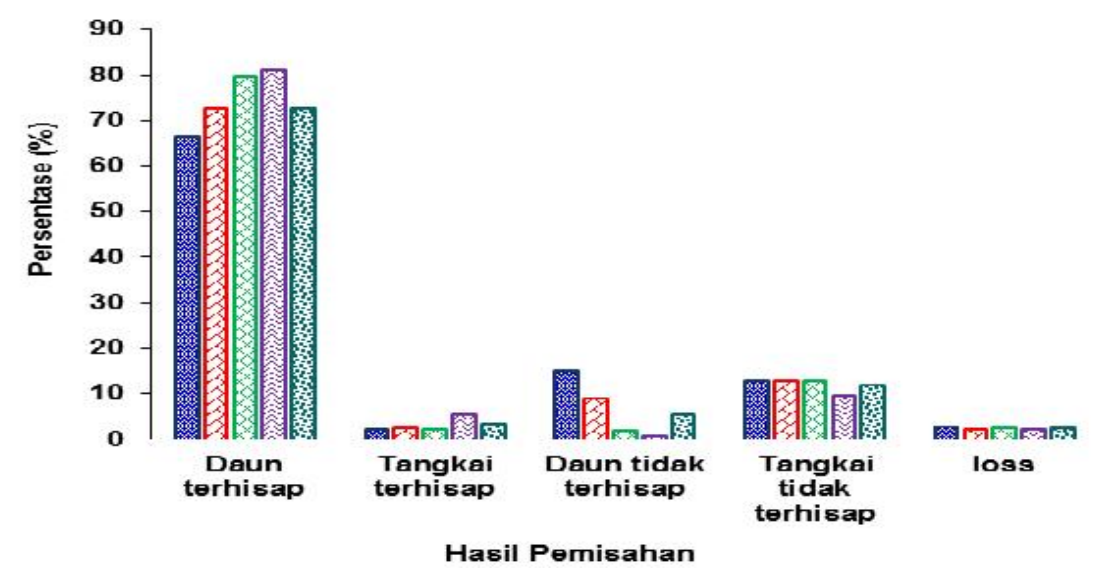

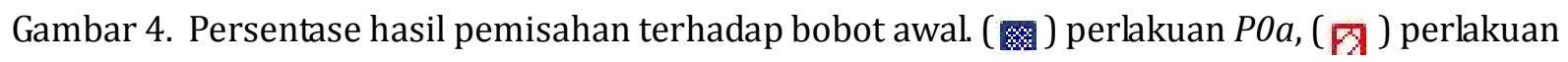
$P 0 b$, (网) perlakuan $P$, (用) perlakuan $P 1 a$, dan (国) perlakuan $P 1 b$

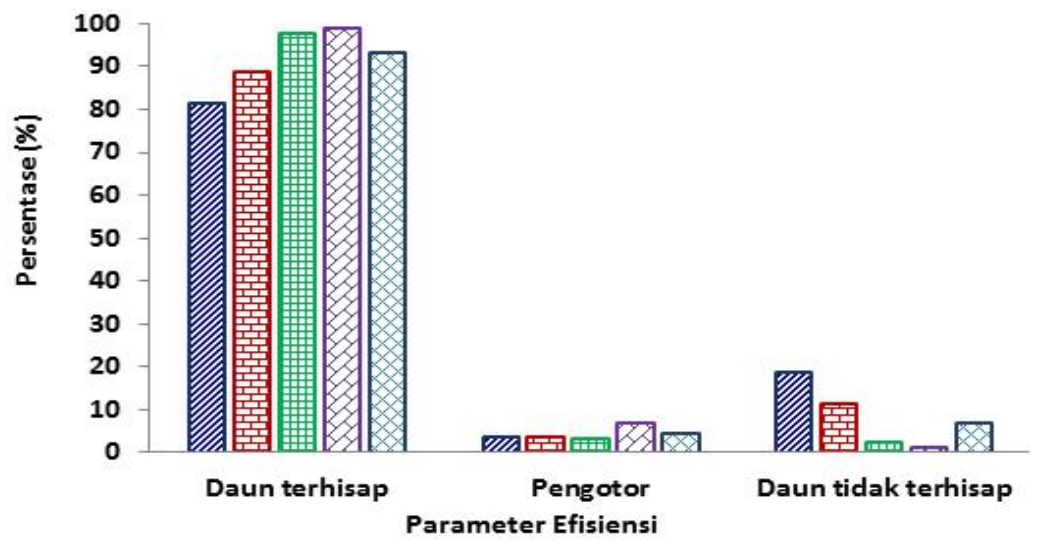

Gambar 5. Hasil pengamatan efisiensi mesin. (細) perlakuan $P 0 a$, (團) perlakuan $P 0 b$, (囘) perlakuan $P$, (因) perlakuan $P 1 a$, dan (国) perlakuan $P 1 b$

Tabel 2. Parameter dan hasil pengujian kapasitas mesin

\begin{tabular}{ccccccc}
\hline $\begin{array}{c}\text { Jumlah } \\
\text { sampel } \\
\text { (g) }\end{array}$ & $\begin{array}{c}\text { Bobot daun } \\
\text { terhisap (g) }\end{array}$ & $\begin{array}{c}\text { Bobot } \\
\text { tangkai } \\
\text { terhisap (g) }\end{array}$ & $\begin{array}{c}\text { Bobot daun } \\
\text { tidak } \\
\text { terhisap (g) }\end{array}$ & $\begin{array}{c}\text { Persentase } \\
\text { daun terhisap } \\
\text { (\%) }\end{array}$ & $\begin{array}{c}\text { Waktu } \\
\text { (s) }\end{array}$ & $\begin{array}{c}\text { Kapasitas } \\
\text { (kg/jam) }\end{array}$ \\
\hline 400 & 331.26 & 5.22 & 7.24 & 97.86 & 3.61 & 330.34 \\
500 & 404.35 & 6.90 & 8.95 & 97.83 & 4.18 & 348.24 \\
600 & 474.35 & 8.35 & 10.61 & 97.81 & 4.82 & 354.29 \\
\hline
\end{tabular}

akan mempengaruhi mutu akhir produk teh. Hasil pengukuran efisiensi mesin ditunjukkan pada Gambar 5. Kombinasi perlakuan $P 1 a$ menghasilkan nilai persentase daun terhisap tertinggi $(98.90 \%)$ namun nilai persentse pengotornya juga tinggi (6.58 \%). Hal tersebut membuat kombinasi perlakuan $P 1 a$ tidak lebih baik dari hasil pengukuran pada kombinasi perlakuan $P$. Kombinasi perlakuan $P$ menghasilkan nilai presentase daun terhisap sebesar $97.6 \%$ dengan nilai pengotor yang rendah, yaitu $2.96 \%$. Dengan demikian efisiensi mesin optimum diperoleh pada kombinasi perlakuan $P$.

\subsection{Kapasitas mesin pemisah potongan tangkai dan daun teh}

Pengujian kapasitas mesin dilakukan pada kombinasi perlakuan yang menghasilkan efisiensi kerja paling optimum, yaitu kombinasi perlakuan $P$. Hasil pengujian disajikan pada Tabel 2. Pengumpanan bahan mula-mula sebesar 0.4 kg pucuk teh. Pada kondisi tersebut, pucuk teh dapat tercacah dengan baik. Saat bahan jatuh di 
atas tray penggetar, tumpukan bahan tidak terlalu banyak sehingga bahan dapat menyebar di permukaan tray dengan baik. Kondisi tersebut menyebabkan potongan daun dapat terhisap lebih mudah sehingga persentase bobot potongan daun terhisap cukup besar, yaitu $97.86 \%$. Pada kondisi tersebut, diperoleh kapasitas mesin sebesar $330.34 \mathrm{~kg} / \mathrm{jam}$.

Pengujian pada pengumpanan $0.5 \mathrm{~kg}$ bahan menghasilkan persentase bobot potongan daun terhisap sebesar $97.83 \%$ dan kapasitas mesin sebesar $348.24 \mathrm{~kg} / \mathrm{jam}$. Sedangkan pada pengumpanan $0.6 \mathrm{~kg}$ dihasilkan persentase bobot potongan daun terhisap sebesar $97.81 \%$ dan kapasitas mesin sebesar $354.29 \mathrm{~kg} / \mathrm{jam}$. Kondisi ini merupakan kondisi paling optimum karena menghasilkan kapasitas mesin paling tinggi dengan nilai persentase bobot potongan daun terhisap yang cukup tinggi. Kapasitas mesin masih dapat ditingkatkan dengan penambahan conveyor sebagai pengumpan sehingga pengumpanan dapat berjalan secara terusmenerus dan konstan. Selain itu, dapat dilakukan pula dengan memodifikasi pencacah agar hasil cacahan lebih baik sehingga mengurangi tangkai yang tidak tercacah sempuna tersangkut pada corong hisap.

\section{KESIMPULAN}

Mesin pemisah potongan tangkai dan daun teh dapat memisahkan dengan baik potongan daun teh dari tangkainya dengan nilai efisiensi pemisahan optimum sebesar $97.60 \%$ pada kecepatan putaran blower 1250 rpm, kecepatan udara hisap rata-rata di permukaan tray sebesar $3.15 \mathrm{~m} /$ detik, dan ketinggian mulut corong hisap ke permukaan tray dari corong 1 sampai dengan corong 6 berturut-turut: $6,5,4,3.5,3,2.5$ dalam satuan sentimeter $(\mathrm{cm})$. Kapasitas kerja optimum mesin sebesar $354.29 \mathrm{~kg} / \mathrm{jam}$.

\section{UCAPAN TERIMA KASIH}

Penulis mengucapkan terima kasih kepada Kementerian Riset, Teknologi dan Pendidikan Tinggi Republik Indonesia yang telah mendanai penelitian ini melalui Beasiswa Pendidikan Pascasarjana Dalam Negeri (BPPDN) dan Program Penelitian Disertasi Doktor (PDD).

\section{DAFTAR PUSTAKA}

[BPS]Badan Pusat Statistik. 2016. Statistik Teh Indonesia 2016. BPS Katalog 5504001. Badan Pusat Statistik (ID). hlm: 5-8.

[FAO]Food and Agriculture Organization. 2018. http://faostatfao.org. [Diakses tanggal 17 Februari 2018].

Ariana, D.P., Notodiputro, K.A., Aunuddin, Guritno, P. 1995. Pendugaan fungsi kepekatan nonparametrik kecepatan terminal fraksi ampas pres minyak sawit. J. Forum Pascasarjana (1995) 18 (2): 69-77.

Gan-Mor, S., Wiseblum, A., Regev, R. 1986. Separation of leaves from stems with a perforated rotating drum under suction. Journal of Agricultural Engineering. 34(...): 275-284.

Gürsoy, S., Güzel, E. 2010. Determination of physical properties of some agricultural grains. Research Journal of Applied Sciences, Engineering and Technology. 2(5): 492 - 498.

Mohsenin, N.N. 1986. Physical Properties of Plant and Animal Materials. New York (US): Gordon and Breach, Science Publisher.

Oyelami, A.K.. 2008. The design of a closed type impeller blower for a $500 \mathrm{~kg}$ capacity rotary furnace. Journal of Engineering Development Institute. 12(1): 50-56.

Panasiewich, M. 1998. Analysis of the pneumatic separation process of agricultural materials. Journal of Agrophysics. 13: 233239.

Rais, M., Bintaro, N., Tamtomo, P. 2005. Analisis proses pemisahan bahan curah secara pneumatik. J. Agrosains. 18(1): 81-94.

Sutejo, A., Mardjan, S.S., Hermawan, H., Desrial. 2018. Design and performance of tea shoots chopper: optimization of stems and leaves separatio. International Journal of Sciantific dan Technology. 7(10): 21-25 